\title{
Correlation analysis between speed bump dimensions and motorcycle speed in residential areas
}

\author{
RA Dinasty Purnomo A ${ }^{1, *}$, Dewi Handayani², and Syafi' $i^{2}$ \\ ${ }^{1}$ Student of Civil Engineering Master Program, Universitas Sebelas Maret, Surakarta, Indonesia \\ ${ }^{2}$ Lecture of Civil Engineering Master Program, Universitas Sebelas Maret, Surakarta, Indonesia
}

\begin{abstract}
Speed bumps have been installed by the community on the streets of the Surakarta city residential area in various sizes to reduce the speed of vehicles passing through the street in order to protect citizens. This paper will analyse the correlation between speed bump dimensions and the observed speed of vehicles in the field. This research was conducted by taking samples from streets in residential areas in Surakarta by observing the decrease of effective speed at a distance of 8 meters before the speed bumps. The independent variables of this study are the width and height of speed bumps $(\mathrm{cm})$ and the dependent variable is speed $(\mathrm{km} / \mathrm{h})$. Data were analysed using a regression equation. The results showed that the height of speed bumps is the most influential factor to decrease speed in the area before the speed bumps.
\end{abstract}

\section{Introduction}

Vehicle speed and crash rate have very strong correlation; therefore, safety can be attributed to speed. Traffic Calming Measures (TCM's) or so-called traffic slowing actions are often implemented to reduce accidents and speed [1]. Traffic delays are a method to address road safety aimed at reducing accidents and fatalities [2]. Limiting vehicular speed is mostly done in developed countries to minimise vehicle acceleration. The effect is not too massive, but speed control measures can reduce vehicular speed [3].

In Indonesia speed control measures often use a vertical speed control device that is used to reduce the speed of vehicles that pass through an area or environment. This device is installed to reduce the frequency of accidents that often occur due to high speeds [4]. On residential roads, vertical speed control devices are often used in the form of sleeping policemen or speed bumps whose installation comes with a variety of dimensions [5]. This is because standard dimensions have not been established for speed bumps. The optimal design of speed bumps is very important to reduce the speed of vertical acceleration produced after passing speed bumps such that road safety is not endangered [6].

\footnotetext{
*Corresponding author: dinasty@ft.uns.ac.id
} 
Based on a literature review, it is indicated that the correlation between the speed of a motorcycle vehicle with the dimensions of speed bumps in field had an impact primarily on the driver in term of safety and discomfort. In other studies, standard dimensions of speed bumps have been used while in Indonesia the dimensions of speed bumps vary widely. Therefore, researchers want to model the correlation between motorcycle speed before passing speed bumps with variations of the speed bumps dimensions that are installed in the residential area of Surakarta.

\section{Theory and method}

\subsection{Speed bumps}

Speed bumps or speed control devices are an additional device of elevation of some road surface transverse to the axis of the road with certain provisions to work so that motor vehicles will reduce their speed [7].

\subsubsection{Installation and placement}

Speed control device are usually installed under [7] the following conditions:

- Placed on residential roads,

- Local road with road level IIIC,

- On road with existing construction work.

Speed bumps are only used on some road conditions [8] as follows:

- Road only serves local access,

- Has no more than one line in each direction,

- The road not a trucking route,

- The location is not close to a fire department, police office or hospital,

- The road is not an area with traffic speeds above $25 \mathrm{mph}$ or $40 \mathrm{~km} / \mathrm{h}$.

\subsubsection{Materials, shapes and sizes of speed bumps}

The materials used to make speed bumps include materials from road bodies, rubber or other materials such as concrete. Material selection is associated with the road user's safety. Speed bumps should also be well constructed to avoid serious damage and inconvenience to passengers and drivers while crossing the speed bumps [9]. Under Indonesian government regulations [7], the cross-sectional shape of speed bumps resembles a prominent trapezoid above the road with a maximum height of $12 \mathrm{~cm}$, with both sides having a $15 \%$ slope. According to the UK department for transportation, speed bumps are a component of traffic calming measures with provisions for road deflection increases of less than $900 \mathrm{~mm}$ and a height of about 50 to $75 \mathrm{~mm}$ [10]. It is mentioned that speed bumps are mounds of asphalt/concrete with a length of $12 \mathrm{ft}$, height 3 " -4 " and placed across the road [8].

\subsection{Correlation of safety and speed}

Road safety is influenced by many factors, including the characteristics of roads, climate, traffic and most importantly vehicle speed [11]. Speed is one of the major risk factors in traffic safety, as speed increases the severity as well as the frequency of the accident [12]. Many studies investigate the correlation between changing speed limits and safety where the result was disregarding the speed limit can negatively affect safety [13]. 
In the regulations, it was mentioned that each road has speed limits defined by national law. In the consideration of safety, the local government can set the highest speed limit stated by traffic signs [14]. However, in some cases many people do not think about the correlation between safety and speed, and the accidents cannot be avoided. Therefore, researchers discussed one way to calm vehicle speed with the installation of the speed bump. It is important to know the correlation between the safe speed bump dimensions and the speed decrease that occurs due to the varied dimensions.

\subsection{Method}

The research was conducted in housing or residential area in Surakarta where speed bumps are often found with the provisions of road width $\pm 3 \mathrm{~m}$, asphalt road, and speed bumps are made of concrete. The vehicle speed observed is the motorcycle speed before passing the speed bumps.

This research used 5 locations and was follow-up study from previous research where 2 locations were used in the previous study. From previous research, it is known that an effective speed decrease was observed at a distance of 8 meters with a large decrease in the average speed of $20.17 \%$ [15]. Therefore, the researchers took the distance of the study at a distance of 8 meters and further points at distances in multiples of $16 \mathrm{~m}$ to determine the speed changes. Fig. 1 shows a sketch of the observation area.

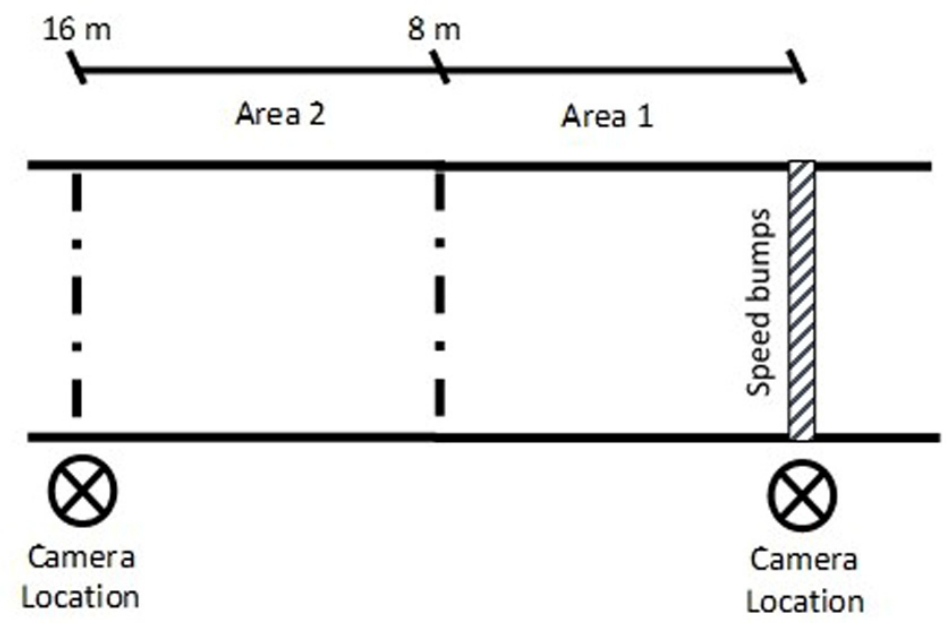

Fig. 1.Vehicle observation area.

The data collection was done by recording using a camera mounted at the points shown in Fig.1. Drop lines indicate locations of artificial lines in field marked with duct tape to identify distance. In addition to the speed measurement, measurements were also done on the dimensions of speed bumps. The survey was conducted during the morning or afternoon rush hour over a 1-3-hour survey period until 30 data samples of random vehicles from each location were obtained so that a total of 150 samples of vehicles from 5 locations was obtained.

\section{Result and discussion}

Research conducted in 5 road locations in Surakarta obtained the average speed of motorcycles. That data can be seen in Table 1 . 
Table 1. Average speed data in the observation area.

\begin{tabular}{|c|c|c|c|c|}
\hline \multirow{2}{*}{ Street Name } & \multicolumn{2}{|c|}{$\begin{array}{c}\text { Average speeds before Speed } \\
\text { Bumps }(\mathrm{km} / \mathrm{h})\end{array}$} & \multirow{2}{*}{$\begin{array}{l}\text { Height of } \\
\text { Speed } \\
\text { Bumps } \\
\text { (cm) }\end{array}$} & \multirow{2}{*}{$\begin{array}{l}\text { Width of } \\
\text { Speed } \\
\text { Bumps } \\
\text { (cm) }\end{array}$} \\
\hline & $\begin{array}{c}V_{\text {area } 1} \\
(\mathbf{K m} / \mathbf{h})\end{array}$ & $\begin{array}{c}V_{\text {area 2 }} \\
(\mathrm{Km} / \mathbf{h})\end{array}$ & & \\
\hline Jl. Sekar Jagad IV & 11.66 & 21.22 & 6.5 & 50 \\
\hline Jl. KP Kadirejo & 12.27 & 23.33 & 3.5 & 33 \\
\hline J1. KP Sewu & 11.18 & 22.28 & 5.5 & 57 \\
\hline Jl. Parang Kusumo & 14.30 & 25.53 & 3 & 32.6 \\
\hline Jl. Mojopahit 1 & 11.80 & 24.54 & 4 & 34.8 \\
\hline
\end{tabular}

Source:Analysis, 2017

The data in Table 1was used for a correlation test as a preliminary analysis to know the correlation between variables. There was a negative relationship between $\mathrm{V}_{\text {area }} 1(8 \mathrm{~m}$ before speed bumps) and $\mathrm{V}_{\text {area }} 2$ (from 8-16 $\mathrm{m}$ before speed bumps) with $\mathrm{X}_{1}$ (height of speed bumps) and $\mathrm{X}_{2}$ (width of speed bumps) as shown in Table 2.

Table 2. Correlation analysis result.

\begin{tabular}{|c|c|c|c|c|}
\hline & $\begin{array}{c}\mathbf{Y} \\
\left(\mathbf{V}_{\text {area }} \mathbf{)}\right.\end{array}$ & $\begin{array}{c}\mathbf{Y} \\
\left(\mathbf{V}_{\text {area }}\right)\end{array}$ & $\mathbf{X}_{\mathbf{1}}$ & $\mathbf{X}_{\mathbf{2}}$ \\
\hline $\mathrm{X}_{1}$ & -0.723 & -0.914 & 1 & 0.877 \\
\hline $\mathrm{X}_{2}$ & -0.675 & -0.797 & 0.877 & 1 \\
\hline
\end{tabular}

Source: Analysis, 2017

Height dimension of speed bumps $\left(\mathrm{X}_{1}\right)$ had a strong positive correlation with width dimensions of speed bumps $\left(\mathrm{X}_{2}\right), 0.877$, that had to be eliminated. Then the height variable of speed bumps $\left(\mathrm{X}_{1}\right)$ was used as the analysis model because it had a negative correlation greater than the width variable of speed bumps $\left(\mathrm{X}_{2}\right)$. Before the regression analysis was done, a linearity test was checked and it was observed that the correlation of $\mathrm{X}$ and $\mathrm{Y}$ spreading does not form a linear line, so nonlinear regression analysis was used.

The selected variable $\mathrm{X}_{1}$ (height of speed bumps) had a regression analysis performed on it using a quadratic model and test of determination coefficient $\left(\mathrm{R}^{2}\right)$ to $\mathrm{Y}$ (velocity) to find out the exact regression line obtained where $\mathrm{V}_{\text {area } 1}(8 \mathrm{~m}$ before speed bumps) was equal to 0.926 and where $\mathrm{V}_{\text {area } 2}$ (from $8-16 \mathrm{~m}$ before speed bumps) was equal to 0.837 . From the results then selected $V_{\text {area } 1}$ had a strong relationship with speed bump height. It known that the height of speed bumps affects the speed of vehicles in area 1 ( $8 \mathrm{~m}$ before speed bumps) by $92.6 \%$.

To know whether the independent variables significantly influence the dependent variable, ANOVA analysis was done by comparing $\mathrm{F}_{\text {table }}$ with $\mathrm{F}_{\text {count }}$. The obtained $\mathrm{F}_{\text {count }}$ was equal to 12.537 with $\mathrm{df}_{1}=2, \mathrm{df}_{2}=2$ and alpha $10 \%$ that equaled 9.000 . Then the value of $\mathrm{F}_{\text {count }}>\mathrm{F}_{\text {tabel }}$ as $12.537>9.000$ states that $\mathrm{X}_{1}$ effect on $\mathrm{Y}$. Thus the obtained mathematics model for the motorcycle average speed on area $1(\mathrm{Y})$ with independent variable being the height dimension of speed bumps $\left(\mathrm{X}_{1}\right)$ was such that $\mathrm{Y}=27.821-6.461 \mathrm{X}_{1}+0.615 \mathrm{X}_{1}^{2}$ with $\mathrm{R}^{2}=0.926$. The best model results were then compared with the field survey as shown in Fig. 2. 


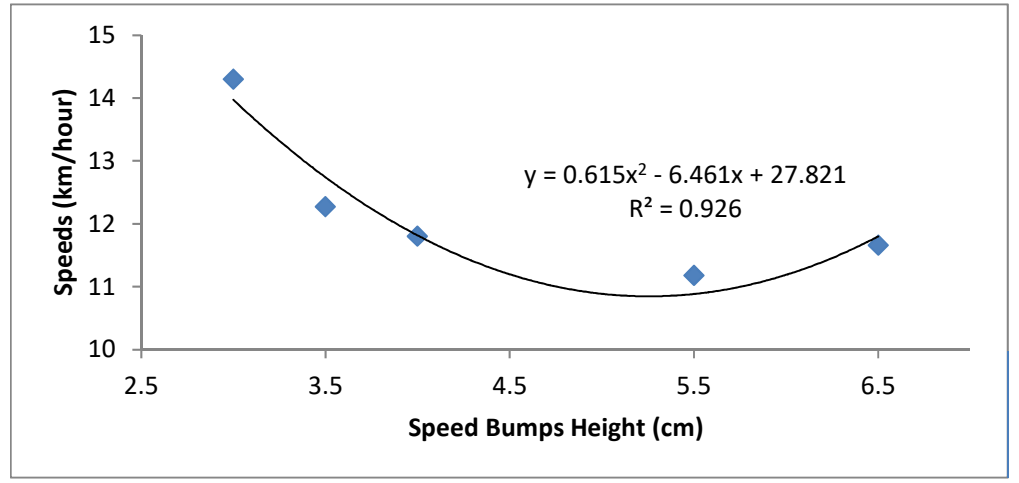

Fig. 2. Bumpschart test best regression model relation between $V a_{\text {rea }} 1$ with height of speed bumps.

From Fig.2., a turning point was observed of $X=5.8 \mathrm{~cm}$ with $\mathrm{Y}=11.04 \mathrm{~km} / \mathrm{h}$. The limit of $X$ in the minimum $Y$ point $=10.85 \mathrm{~km} / \mathrm{h}$ obtained the maximum limit of $\mathrm{X}=5.2$ $\mathrm{cm}$ for decreasing speed. In relation to the theory that vehicle speed had a parabolic relationship with the dimensions of speed bumps, the maximum height limit $X=5.2 \mathrm{~cm}$ was applied to this model.

\section{Conclusion and suggestion}

The non-linear regression equation of a quadratic model on motorcycles speed showed a decrease in speed $\left(\mathrm{V}_{\text {areal }}\right)$ due to height of speed bumps $\left(\mathrm{X}_{1}\right)$ where $\mathrm{Y}=27,821-6,461 \mathrm{X}_{1}+$ $0,615 \mathrm{X}_{1}^{2}$ with $\mathrm{R}^{2}$ equal to 0.926 with this model being valid for height bumps $\leq 5.2 \mathrm{~cm}$.

In further research it may be possible to extend the modelling analysis to know the correlation of width of speed bumps with speed decrease, and the influence between speed bumps' design in the field and the speed decrease to obtain optimal dimensions.

\section{References}

1. A.T. Moreno, A. Garcia. Accid. Anal. Prev.61, 23-32 (2013)

2. A. García, A.J. Torres, M.A. Romero, A.T. Moreno. Procedia Soc. Behav. Sci.16, 270281 (2011)

3. N. Agerholm, D. Knudsen, K. Variyeswaran. Transp. Res. F Traffic Psychol. Behav.46, 263-270 (2017)

4. B.S. Ajiwijaya. Pengaruh Alat Pengendali Kecepatan Vertikal, Lebar Jalan dan Jarak Pemasangan Terhadap Kecepatan (Di Lingkungan Permukiman) (Skripsi Universitas Sebelas Maret, Surakarta, 2014)

5. D. Handayani, F.K. Hermawan, A.M. Mahmudah. Matriks Teknik Sipil UNS, 4, 1 (2016)

6. A.H. Lav, E. Bilqin, A.H. Lav. Accid. Anal. Prev.116, 53-68 (2018)

7. Republik Indonesia, Keputusan Menteri Perhubungan Nomor 3 Tahun 1994 Tentang Alat pengendali dan Pengamanan Pemakai Jalan (Depertemen Perhubungan, Jakarta, 1994)

8. S.H. Wolfgang. Fundamental of Traffic Engineering, Institute of Transportation Studies, University of California at Berkeley, Berkeley (1992) 
9. E.J. Arianto. Analisis pengaruh speed humps terhadap kecepatan (Thesis Program Pascasarjana Univesitas Diponegoro, Semarang, 2005)

10. Traffic Calming, Local Transport Note 1/07, Department for Transport, Department for Regional Development (Northern Ireland), Scottish Executives (Welsh Assembly Government, TSO, 2007)

11. S.A. Gargoum, K. El-Basyouny. Accid. Anal. Prev.93, 32-40 (2016)

12. E.D. Pauw, S. Daniels, M. Thierie, T. Brijs. Accid. Anal. Prev.62, 426-431 (2014)

13. T. Sayed, E.Sacchi. Accid. Anal. Prev.95, 172-177 (2016)

14. Republik Indonesia, Undang-undang Nomor 22 Tahun 2009 tentang Lalu lintas dan Angkutan Jalan. Lembaran Negara Republik Indonesia (No. 5025, Sekretariat Negara, Jakarta, 2009)

15. D.A. Sari. The effective distance of speed reduction on upper course of speed bump : a case study in Surakarta region (Skripsi Universitas Sebelas Maret, Surakarta, 2017) 